Article

\title{
Evaluation of the Impact of Different Management Methods on Tetranychus urticae (Acari: Tetranychidae) and Their Predators in Citrus Orchards
}

\author{
Amine Assouguem 1,2,*(D), Mohammed Kara ${ }^{3}$ (D) , Hamza Mechchate ${ }^{4, *(\mathbb{D},}$, Fahd A. Al-Mekhlafi ${ }^{5}$, Fahd Nasr ${ }^{6}$, \\ Abdellah Farah ${ }^{2}$ and Abderahim Lazraq ${ }^{1}$
}

1 Laboratory of Functional Ecology and Environment, Faculty of Sciences and Technology, Sidi Mohamed Ben Abdellah University, Fez 30000, Morocco; lazraqab@gmail.com

2 Laboratory of Applied Organic Chemistry, Faculty of Sciences and Technology, Sidi Mohamed Ben Abdellah University, Fez 30000, Morocco; farah.abdellah1@gmail.com

3 Laboratory of Biotechnology and Conservation and Valorization of Natural Resources (LBCVRN) (Ex LBPRN), Sidi Mohamed Ben Abdellah University, Fez 30000, Morocco; mohammed.kara@usmba.ac.ma

4 Laboratory of Inorganic Chemistry, Department of Chemistry, University of Helsinki, P.O. Box 55, FI-00014 Helsinki, Finland

5 Department of Zoology, College of Science, King Saud University, Riyadh 11451, Saudi Arabia; falmekhlafi@ksu.edu.sa

6 Department of Pharmacognosy, College of Pharmacy, King Saud University, Riyadh 11451, Saudi Arabia; fahdnasr74@gmail.com

* Correspondence: assougam@gmail.com (A.A.); hamza.mechchate@helsinki.fi (H.M.)

\section{check for} updates

Citation: Assouguem, A.; Kara, M.; Mechchate, H.; Al-Mekhlafi, F.A.; Nasr, F.; Farah, A.; Lazraq, A. Evaluation of the Impact of Different Management Methods on Tetranychus urticae (Acari: Tetranychidae) and Their Predators in Citrus Orchards. Plants 2022, 11, 623. https://doi.org/ $10.3390 /$ plants 11050623

Academic Editors: Špela Mechora, Dragana Šunjka and Fabrizio Araniti

Received: 8 January 2022

Accepted: 21 February 2022

Published: 25 February 2022

Publisher's Note: MDPI stays neutral with regard to jurisdictional claims in published maps and institutional affiliations.

Copyright: (C) 2022 by the authors. Licensee MDPI, Basel, Switzerland. This article is an open access article distributed under the terms and conditions of the Creative Commons Attribution (CC BY) license (https:// creativecommons.org/licenses/by/ $4.0 /)$.

\begin{abstract}
To evaluate the effectiveness of eco-friendly treatments based on detergents classified as non-hazardous and black soap on the pest Tetranychus urticae Koch 1836, and their predators (Euseius stipulatus Athias-Henriot, 1960, Typhlodromus sp., Phytoseiulus persimilis Athias-Henriot, 1957), different treatments were applied to citrus orchards planted with Valencia late (Orange) in the Mechraa Belksiri region of Morocco ( $\mathrm{T} 0=$ control experiment; $\mathrm{T} 1$ = spirodiclofen $0.5 \mathrm{~L} / \mathrm{Ha}$; $\mathrm{T} 2=125 \mathrm{~L} / \mathrm{Ha}(5 \%)$ of black soap; T3 = detergent; $4 \mathrm{~L} / \mathrm{Ha}$ of Oni product $+2 \mathrm{~L} / \mathrm{Ha}$ of Tide product). The results obtained during the whole monitoring period indicated that the three treatments used, namely spirodiclofen, black soap, and detergents, ensured a reduction in the rate of population of the pest T. urticae compared to the untreated plot. In the untreated plot, the average was $45.01 \mathrm{~A} \pm 4.90$ mobile forms, while the plot treated with spirodiclofen it was only $21.10 \mathrm{C} \pm 2.71$, the black soap $31.49 \mathrm{~B} \pm 3.35$, and in the plot treated with detergents, the average was similar to that obtained by spirodiclofen $(22.90 \mathrm{C} \pm 2.18)$. On the predators (E. stipulatus, P. persimilis, and Typhlodropmus sp.), the black soap and the treatment with detergents were less harmful compared to the chemical spirodiclofen.
\end{abstract}

Keywords: Tetranychus urticae; Euseius stipulatus; Typhlodromus sp.; Phytoseiulus persimilis; citrus orchard; monitoring; predators; pest; treatments

\section{Introduction}

Citrus is one of the world's major fruit crops and is grown in over 100 countries [1]. It belongs to the Rutaceae family, with 140 genera and 1300 species, including fundamental groups like orange, lemons, mandarin, and pummelos. They are cultivated in tropical and subtropical areas [2]. The total worldwide production of citrus is 139.80 million tons [3].

In Morocco, thanks to the Ministry of Agriculture, citrus orchards have reached 130,000 ha with a total annual production of over 2.2 million tons [4]. However, the yield at the national level is still low compared to that achieved by other European and American countries [5]. The Ministry of Agriculture is currently trying to remedy constraints that 
are hampering the increase of citrus production, including lack of manpower, maturity of orchards, and biotic and abiotic constraints [6,7]. The negative impact caused by pests reduces the quantity and quality of production. Indeed, spider mites, aphids, medflies, and diaspine scales are pests of primary economic importance $[8,9]$. When conditions are favorable and in the absence of adequate methods of control, significant damage is often observed on the fruits, twigs, leaves, and young shoots of citrus [10]. Tetranychus urticae Koch, 1836 is an economically major pest to agricultural crops and ornamental plants throughout the world [11], being found in Europe, Asia, Africa, the Caribbean islands, and North America [12]. It is known for developing a resistance to pesticides [13], and causes significant damage to agricultural crops, such as defoliation, leaf yellowing, and leaf burning [14,15]. Euseius stipulatus Athias-Henriot, 1960 (Acari: Phytoseiidae), Phytoseiulus persimilis Athias-Henriot, 1957 (Acari: Phytoseiidae), and Typhlodromus sp. (Acari: Phytoseiidae) are the main predators of T. urticae in many regions of the world $[16,17]$. Spirodiclofen (Envidor 240 SC, Bayer, SA) is an acaricide of the keto-enol family. It acts by contact and ingestion as an inhibitor of lipid biosynthesis (LBI) [18]. It has a powerful ovicidal action, controls all juvenile stages, and significantly reduces fertility in females [19].

Black soap, brown in color, is biodegradable, non-polluting, and an excellent insecticide [20]. This product is effective against insects like mealy bugs, aphids, whiteflies, thrips, and spider mites. Through simple contact, it blocks the respiratory pores [2,21]. It does not produce toxic residues and does not affect natural predators. These products are approved by organic agriculture (EEC regulation 2092/91). To minimize the negative impact of these pests on citrus production, the use of chemical applications is often the solution adopted by growers [22,23]. Spirodiclofen often gives good results in the control of spider mites, namely, the biological parameters, including developmental time, survival rate, and in particular, the fecundity of $T$. urticae $[24,25]$. The misuse of this active ingredient often has harmful impacts on the agroecosystems [26,27]. The development of new eco-friendly approaches is a necessity. In this context, our study aims to evaluate the impact of spirodiclofen, black soap, and a mixture of two detergents (Oni and Tide products) on the pest T. urticae and its predators (E. stipulatus, Typhlodromus sp., and P. persimilis).

\section{Materials and Methods}

\subsection{Study Area}

This study was performed in Mechra Bel Ksiri, located north of Oued Sebou in the Gharb region, at an altitude of 300-500 $\mathrm{m}$ above sea level (Figure 1) [28]. The climate is temperate to hot. This region is well known for the production of citrus fruits, cereals, and vegetable crops due to the suitable properties of the climate and soil [29]. The Gharb region is characterized by a Mediterranean climate with annual precipitation ranging between 480 and $600 \mathrm{~mm} /$ year, and an average temperature of $27^{\circ} \mathrm{C}$ in summer and $13^{\circ} \mathrm{C}$ in winter [30].

\subsection{Sampling Design}

A Valencia late (Citrus sinensis) orchard with a high spider mite infestation was selected to study the impact of spirodiclofen, black soap, and a mixture of two detergents (Oni product and Tide product) on Tetranychus urticae populations and their predators. Spirodiclofen was used because of its effectiveness against a wide range of biting/sucking pests, including spider mites. The orchard covers 4 ha of Valencia late trees. The orchard was divided into 4 plots of 1 ha (Figure 2), and each plot was treated with a specific dose of the treatment: (i) T0 treated with water only (as a control experiment), (ii) T1 = spirodiclofen $0.5 \mathrm{~L} / \mathrm{Ha}$, which is the recommended dose for treating citrus mites, (iii) T2 $=125 \mathrm{~L} / \mathrm{Ha}$ (5\%) of black soap, and (iv) T3 = detergent $4 \mathrm{~L} / \mathrm{Ha}$ of Oni product (sodium C14-17 alkyl sec sulfonate, sodium C12-13 pareth sulfate) and $2 \mathrm{~L} / \mathrm{Ha}$ of Tide product (sodium C10-16 alkylbenzene sulfonate, sodium borate, and propylene glycol). These two detergents are often used by local farmers to control pests and minimize the use of pesticides. They are not classified as hazardous, according to the European directive 99/45/EC on dangerous prepa- 
rations [31]. The treatments were applied with the Teyme Eolo sprayer (Teyme Tecnologia Agricola, Girona, Spain), with turbulent nozzles $12 \mathrm{~mm}$ in diameter, delivering $1.55 \mathrm{~L} / \mathrm{min}$ at 20 bar pressure. The towed sprayer delivers $2500 \mathrm{~L}$ of spray liquid per hectare, at a rate of $6 \mathrm{~L}$ of spray solution for each tree (Figure 2). To evaluate the effect of each product used, a block of 10 trees was selected and monitored weekly. Ten leaves were collected from each tree, from different directions (north, east, south, and west) and at different heights of the tree (10 replicates were performed independently) [32-34]. We left two untreated lines $(12 \mathrm{~m})$ between the different treated plots to avoid overlapping treatments. The total number of predators (P. persimilis, Typhlodromus sp., and E. stipulatis) and phytophagous mite (T. urticae) found on the 10 leaves of each plot was recorded [35]. All mites, except eggs and mites in quiescence, were counted on both sides of each leaf with a professional eye loop $10 \times$. Then, to confirm the number of mites on each leaf, the collected leaves were transferred directly into polyethylene bags referenced to the laboratory for observation under a binocular microscope. Inspections were conducted 3 days after the treatment: 12 April (week 1), 19 April (week 2), 26 April (week 3), 3 May (week 4), 10 May (week 5), 17 May (week 6), 24 May (week 7), and 1 June (week 8).

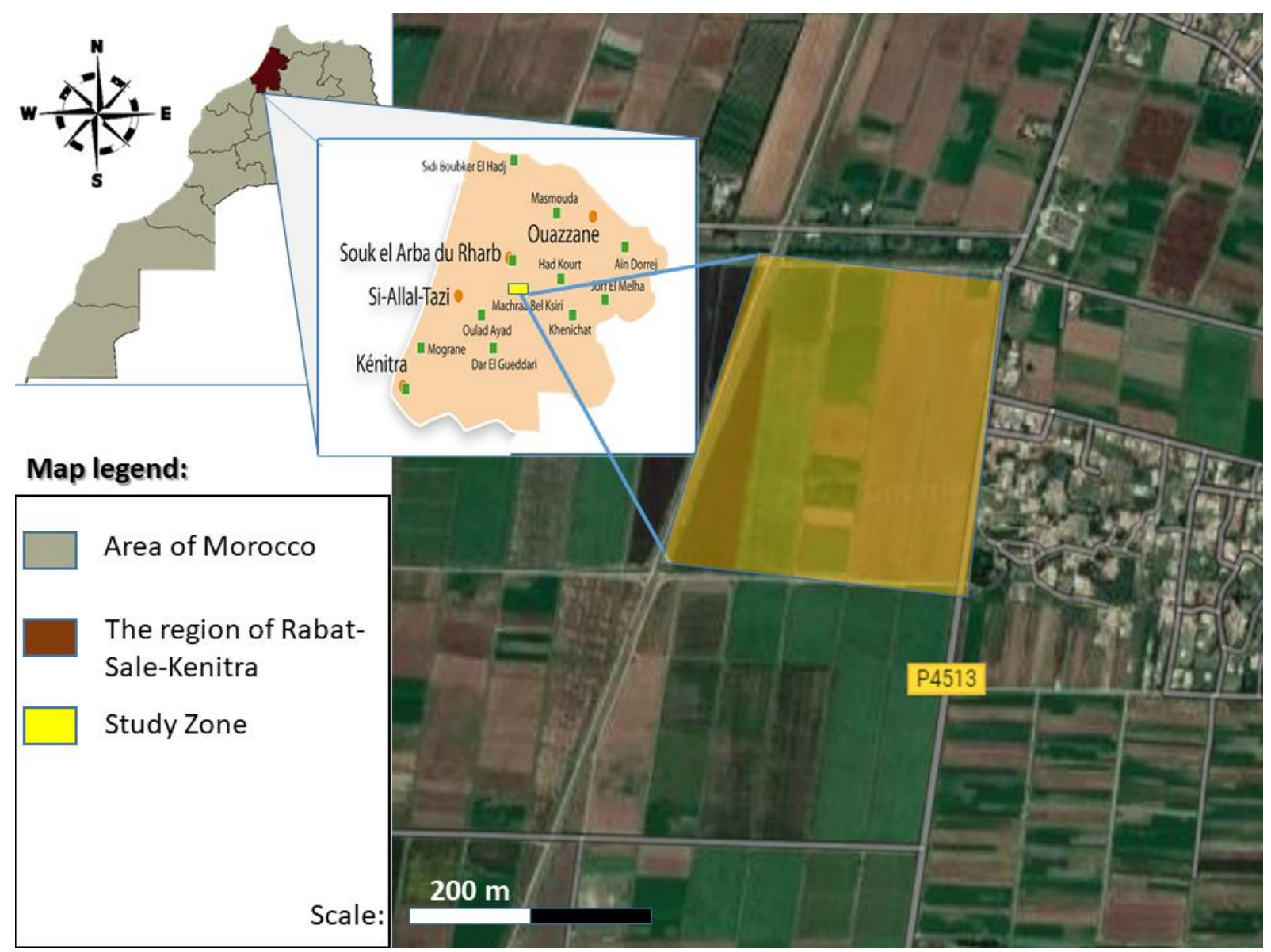

Figure 1. Location of experimental orchards. 


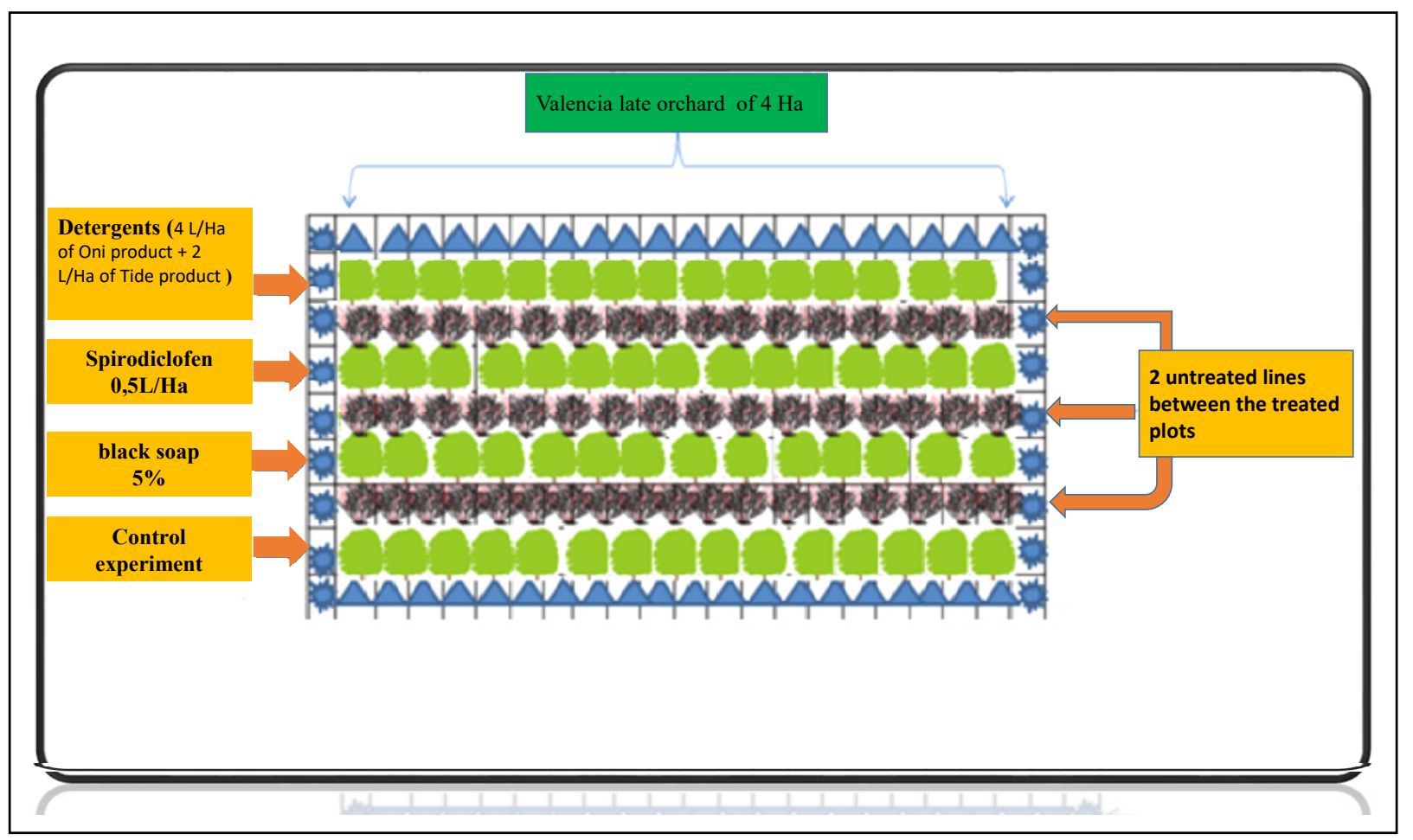

Figure 2. The different types of treatments used in the citrus orchard.

\subsection{Statistics}

Statistics of the data were performed using Minitab software, version 1.1.19, Minitab, Sydney, NSW, Australia. The results were given as percentage and mean \pm SD. In order to evaluate the effectiveness of the treatments used on the pests and predators, we calculated the average of mobile forms found of $\mathrm{T}$. urticae in $(\mathrm{T} 0=$ control experiment; $\mathrm{T} 1=$ plot treated with spirodiclofen; T2 = plot treated with black soap; T3 = plot treated with a mixture of two detergents). In parallel, we evaluated the impact of the treatments on natural enemies. We calculated the averages of each predator (P. persimilis, Typhlodromus sp. and E. stipulatis) in T0, T1, T2, and T3 [36]. We tested for normality and homogeneity of variance for all variables with the Kolmogorov-Smirnov test. The impact of treatments, monitoring dates, and their interactions was compared using the general linear model (GLM) univariate, followed by a post hoc Tukey test at $p<0.05$. The principal component analyses (PCA) were accomplished using Minitab 19.1 software (Minitab, State College, PA, USA) to elucidate the relationship between the different mites studied and the treatments tested.

\section{Results}

\subsection{Leaf Occupancy Rate by Mites in the Different Plots}

During the whole monitoring period, on the untreated plot, the occupancy of the inspected leaves by the pest Tetranychus urticae was $n=3601$ mobile forms (54\%); moreover, the predator Typhlodromus sp. presented the most important proportion with $18 \%(n=1212)$, followed by P. persimilis with $15 \%(n=1032)$ and E. stipulatus with $13 \%(n=838)$.

In the plot treated with spirodiclofen, the abundance of these mites was low compared to the untreated plot. The pest T. urticae presented $46 \%$ with 1688 mobile forms. The predator P. persimilis presented $22 \%(n=805)$, while E. stipulatus and Typhlodromus sp. presented the same proportion of $16 \%$ ( $n=595$ and $n=571$, respectively).

In the plot managed with black soap, we recorded 2519 mobile forms (50\%) for the pest T. urticae, $19 \%(n=948)$ for the predator P. persimilis, $17 \%(n=832)$ for Typhlodromus sp., and only $14 \%(n=728)$ for E. stipulatus. 
In the plot treated with detergents, we recorded $42 \%(n=1832)$ of T. urticae, $23 \%$ $(n=1022)$ of P. persimilis, $18 \%(n=809)$ of Typhlodromus sp., and $17 \%(n=766)$ of E. stipulatus (Figure 3).

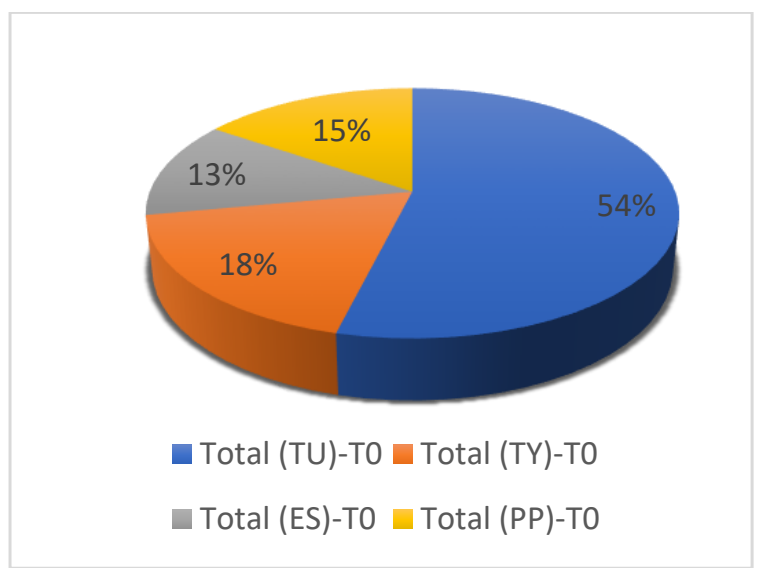

(a)

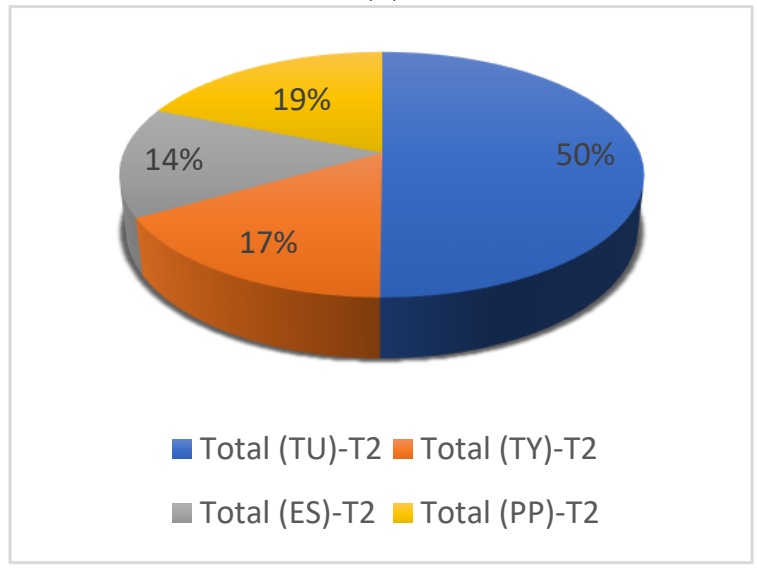

(c)

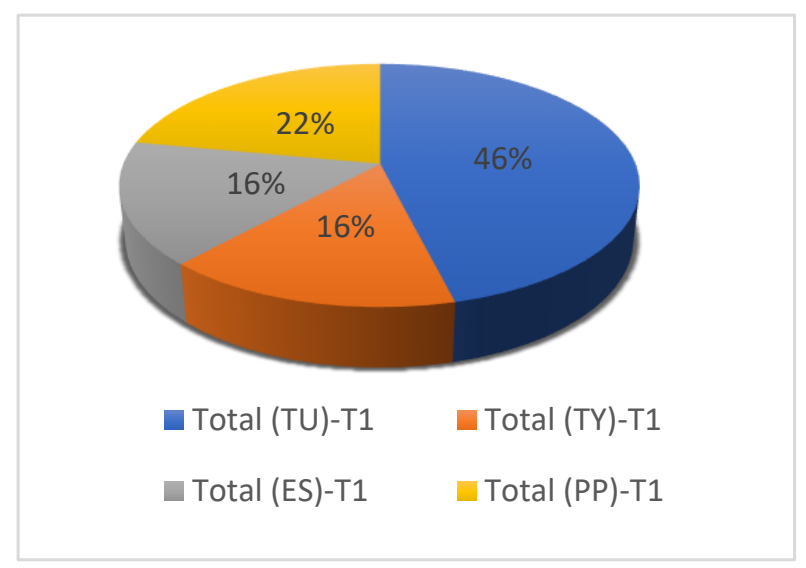

(b)

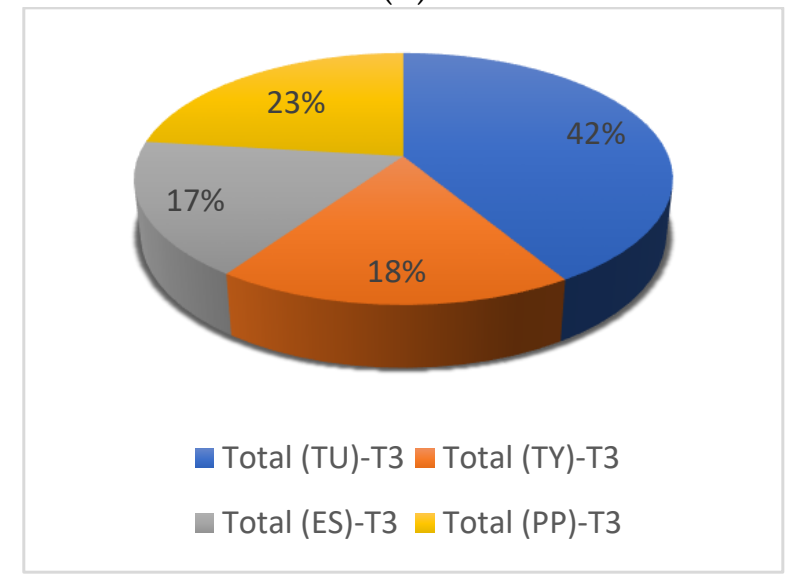

(d)

Figure 3. The proportion of the different mites studied (the phytophagous mite Tetranychus urticae (TU) and their predators Euseius stipulatus (ES), Typhlodromus sp. (TY), and Pytoseiulus persimilis $(\mathrm{PP})$ ) according to the treatments used $(\mathrm{T} 0=$ control experiment; $\mathrm{T} 1=$ spirodiclofen $0.5 \mathrm{~L} / \mathrm{Ha}$; $\mathrm{T} 2=125 \mathrm{~L} / \mathrm{Ha}(5 \%)$ of black soap; T3 = $4 \mathrm{~L} / \mathrm{Ha}$ of Oni product $+2 \mathrm{~L} / \mathrm{Ha}$ of Tide product). (a) Control experiment; (b) Spirodiclofen $0.5 \mathrm{~L} / \mathrm{Ha}$; (c) Black soap $125 \mathrm{~L} / \mathrm{Ha}$; (d) T3 = Mixture of two detergents.

\subsection{The Influence of Treatments on the Different Mites Studied}

Regarding the effect of the different treatments used on the mites studied, the treatment with detergents and spirodiclofen showed the highest efficiency on the populations of the pest T. urticae (Figure 4), while on the predators (E. stipulatus, P. persimilis, and Typhlodropmus $\mathrm{sp}$.), the black soap and the treatment with detergents were less harmful compared to the chemical product (spirodiclofen). Table 1 confirms these results; spirodiclofen treatment significantly reduced $T$. urticae populations with a mean of $21.10 \mathrm{C} \pm 2.71$ compared to the control (45.01 A \pm 4.90 ). The same result was observed with the detergent treatment, which reduced the T. urticae levels to an average of $22.90 \mathrm{C} \pm 2.18$. Black soap provided a significant reduction for the mean of this pest (31.49 $\mathrm{B} \pm 3.35)$ compared to the control; however, this treatment was less effective on T. urticae compared to the treatment with spirodiclofen and detergents. 


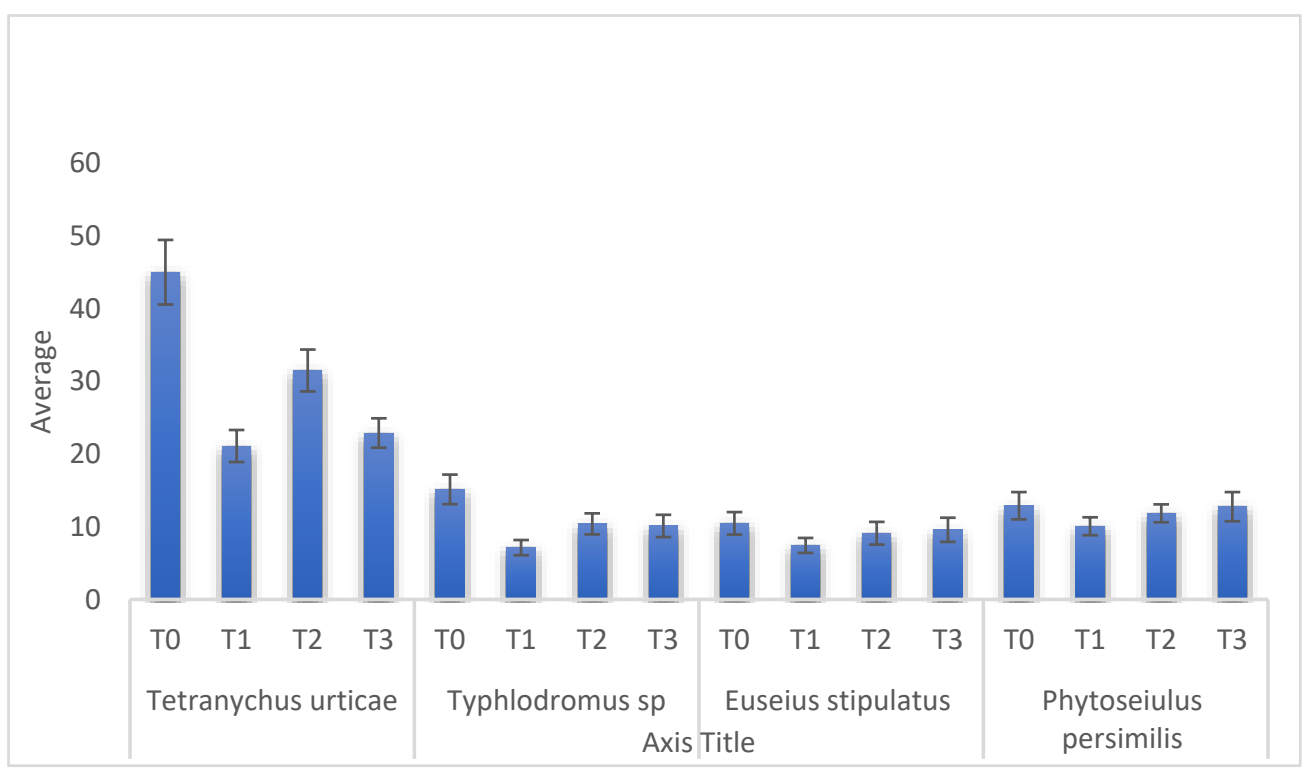

Figure 4. Comparison between the means of different mites according to the treatments $(\mathrm{T} 0=$ control experiment; $\mathrm{T} 1$ = spirodiclofen $0.5 \mathrm{~L} / \mathrm{Ha} ; \mathrm{T} 2=125 \mathrm{~L} / \mathrm{Ha}(5 \%)$ of black soap; $\mathrm{T} 3=$ detergents; $4 \mathrm{~L} / \mathrm{Ha}$ of Oni product $+2 \mathrm{~L} / \mathrm{Ha}$ of Tide product).

Table 1. The impact of different treatments used on the mites studied (TU: T. urticae; ES: E. stipulatus; TY: Typhlodromus sp.; PP: P. persimilis) in citrus orchards. Values in the same column with different superscripts are significantly different $(p<0.05)$.

\begin{tabular}{ccccc}
\hline & TU & TY & ES & PP \\
\hline Control experiment (T0) & $45.01^{\mathrm{A}} \pm 4.90$ & $15.15^{\mathrm{A}} \pm 1.83$ & $10.47^{\mathrm{A}} \pm 1.63$ & $16.02^{\mathrm{A}} \pm 2.12$ \\
Spirodiclofen 0.5 L/Ha (T1) & $21.10^{\mathrm{C}} \pm 2.71$ & $7.13^{\mathrm{C}} \pm 1.28$ & $7.44^{\mathrm{B}} \pm 1.37$ & $10.06^{\mathrm{B}} \pm 1.15$ \\
Black soap 5\% (T2) & $31.49^{\mathrm{B}} \pm 3.35$ & $10.40^{\mathrm{B}} \pm 2.05$ & $9.10^{\mathrm{AB}} \pm 1.25$ & $11.85^{\mathrm{AB}} \pm 1.11$ \\
Detergent (T3) & $22.90^{\mathrm{C}} \pm 2.18$ & $10.11^{\mathrm{B}} \pm 2.14$ & $9.57^{\mathrm{AB}} \pm 1.47^{\mathrm{B}}$ & $14.68^{\mathrm{A}} \pm 1.87^{-14}$ \\
\hline
\end{tabular}

The highest average of Typhlodromus sp. was in the water treatment, with an average of $15.15 \mathrm{~A} \pm 1.83$ and the treatment with black soap (T3) and detergents (T4) were less harmful on the predator Typhlodromus sp. with the means of $10.40 \mathrm{~B} \pm 2.05$ for the plot treated with black soap and $10.11 \mathrm{~B} \pm 2.14$ for the one sprayed with detergents, while the treatment with spirodiclofen (T2) had the most harmful impact on the population of Typhlodromus sp., with an average of $7.13 \mathrm{C} \pm 1.28$.

For the predator E. stipulates, the average was $10.47 \mathrm{~A} \pm 1.63$ in the plot treated with water (T0), while it was $9.10 \mathrm{AB} \pm 1.25$ in the plot treated with black soap (T3), and $9.57 \mathrm{AB} \pm 1.47$ in the plot treated with detergents (T4). The average of this population was low in the plot treated with the chemical product spirodiclofen, with a mean of $7.44 \mathrm{~B} \pm 1.37$.

On $P$. persimilis populations, the treatment with detergents was the least harmful, with an average $(14.68 \mathrm{~A} \pm 1.87)$ nearly similar to that for the plot treated only with water (16.02 $\mathrm{A} \pm 2.12$ ). With black soap, the average was $11.85 \mathrm{AB} \pm 1.11$, whereas the plot treated with spirodiclofen was $10.06 \mathrm{~B} \pm 1.15$.

In Figure 5, the eigenvalues of the first two principal components explain $92.7 \%$ of the variation in the data. The first principal component explains $86.5 \%$ of the total variance. The variables with the highest association with the first principal component (CP1) are T. urticae (0.50), E. stipulatus (0.50), and P. persimilis (0.50), while the variable Typhlodromus sp. $(-0.75)$ is negatively associated with the second principal component (CP2). However, the projection of the scoring and the contribution diagram can visually show a positive contribution of the four mites studied (T. urticae, P. persimilis, Typhlodromus sp. and E. stipulatis) 
on the first main axis in positive correlation with T0 water treatment, while spirodiclofen (T2), detergents (T4), and black soap (T3) treatment were correlated negatively.
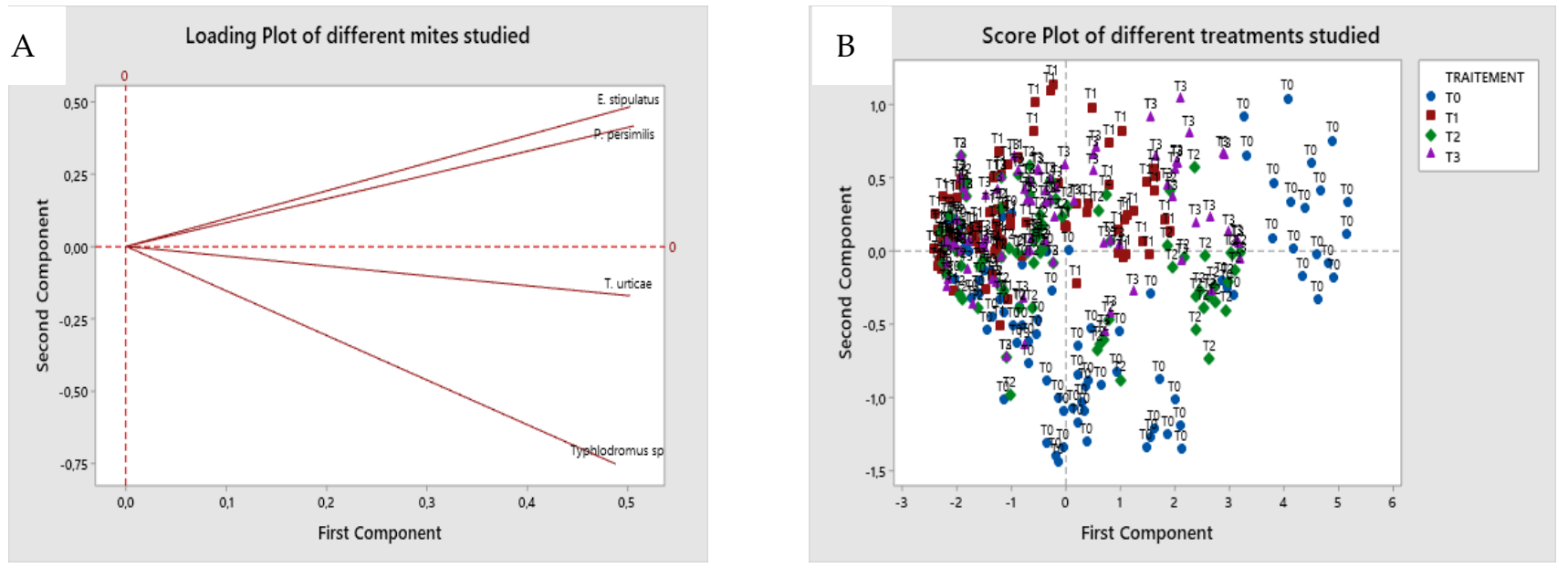

Figure 5. Principal component analysis (PCA) of the different mites studied (T. urticae; E. stipulatus; Typhlodromus sp.; P. persimilis) according to the different treatments (T0 = control experiment; $\mathrm{T} 1$ = spirodiclofen $0.5 \mathrm{~L} / \mathrm{Ha} ; \mathrm{T} 2=125 \mathrm{~L} / \mathrm{Ha}(5 \%)$ of black soap; T3 = detergents; $4 \mathrm{~L} / \mathrm{Ha}$ of Oni product $+2 \mathrm{~L} / \mathrm{Ha}$ of Tide product) (A); double projection diagram for the two components (B).

\subsection{Fluctuation of Mites According to Treatments and Follow-Up Dates}

According to the results in Table 2, we can conclude that the interaction between the treatment used and the monitoring dates has a significant effect on the variation of the means of the different mites studied. During the first week, three days after the spraying of the treatments, we observed a significant decrease in the rate of T. urticae; we had an average of $6.30 \mathrm{~F} \pm 1.16$ for the spirodiclofen, $8.20 \mathrm{E} \pm 1.69$ for the black soap (Table 3), and $07.00 \mathrm{~F} \pm 1.49$ for the detergent treatment. In contrast, in the untreated plot $\mathrm{T} 0$, and during the same week (W1), this average almost doubled $14.30 \mathrm{E} \pm 2.00$. Despite the increase in temperature from 27 to $34{ }^{\circ} \mathrm{C}$ from week 1 to week 5 (Table 3), the rate of T. urticae had a slight increase during the first five weeks after treatment with spirodiclofen compared to the average reached in the untreated plot (Figure 6). In week 5, these averages were $16.30 \mathrm{D} \pm 1.41$ in the plot treated with spirodiclofen and $36.00 \mathrm{C} \pm 2.35$ in the untreated plot. Beyond that, this pest had a significant increase during the last three weeks to reach an average of $53.60 \mathrm{~A} \pm 4.77$ in the plot treated with spirodiclofen (T1), and 86.60 $\mathrm{A} \pm 7.06$ in the untreated plot during week 8 , where the temperature reached $39{ }^{\circ} \mathrm{C}$.

Table 2. General linear model (GLM) of analysis of variance for the mean density of T. urticae (a), Typhlodromus sp. (b), P. persimilis (c), and E. stipulatus (d) according to the treatments, monitoring dates, and their interactions.

\begin{tabular}{cccccc}
\hline & \multicolumn{5}{c}{ (a) T. urticae } \\
\hline Source & DF & Adj SS & Adj MS & F-Value & $p$-Value \\
\hline Monitoring dates & 7 & 135.717 & $19,388.1$ & 1579.57 & $0.000^{*}$ \\
Treatments & 3 & 28.572 & 9523.9 & 775.92 & $0.000 *$ \\
M. dates * Treatments & 21 & 18.865 & 898.4 & & \\
Error & 288 & 3535 & 12.3 & \\
Total & 319 & 186.689 & & \\
\hline
\end{tabular}

(b) Typhlodromus sp.

\begin{tabular}{cccccc}
\hline Source & DF & Adj SS & Adj MS & F-Value & $p$-Value \\
\hline Monitoring dates & 7 & 7966.9 & 1138.13 & 211.42 & $0.000 *$ \\
Treatments & 3 & 2634.3 & 878.11 & 163.12 & $0.000 *$ \\
\hline
\end{tabular}


Table 2. Cont.

\begin{tabular}{|c|c|c|c|c|c|}
\hline $\begin{array}{c}\text { M. dates * Treatments } \\
\text { Error } \\
\text { Total }\end{array}$ & $\begin{array}{c}21 \\
288 \\
319 \\
\end{array}$ & $\begin{array}{c}579.6 \\
1550.4 \\
12,731.2 \\
\end{array}$ & $\begin{array}{c}27.60 \\
5.38\end{array}$ & 5.13 & $0.000 *$ \\
\hline \multicolumn{6}{|c|}{ (c) P. persimilis } \\
\hline Source & DF & Adj SS & Adj MS & F-Value & $p$-Value \\
\hline Monitoring dates & 7 & 30,048 & 4292.56 & 473.97 & $0.000 *$ \\
\hline Treatments & 3 & 1745 & 581.70 & 64.23 & $0.000 *$ \\
\hline M. dates * Treatments & & 3012 & 143.44 & 15.84 & $0.000 *$ \\
\hline Error & 288 & 2608 & 9.06 & & \\
\hline Total & 319 & 37,413 & & & \\
\hline \multicolumn{6}{|c|}{ (d) E. stipulatus } \\
\hline Source & DF & Adj SS & Adj MS & F-Value & $p$-Value \\
\hline Monitoring dates & 7 & 8996.3 & 1285.19 & 304.76 & $0.000 *$ \\
\hline Treatments & 3 & 389.7 & 129.90 & 30.80 & $0.000 *$ \\
\hline M. dates * Treatments & & 409.6 & 19.50 & 4.62 & $0.000 *$ \\
\hline Error & 288 & 1214.5 & 4.22 & & \\
\hline Total & 319 & $11,010.1$ & & & \\
\hline
\end{tabular}

* Statistically significant $p$-values $(p<0.05)$.
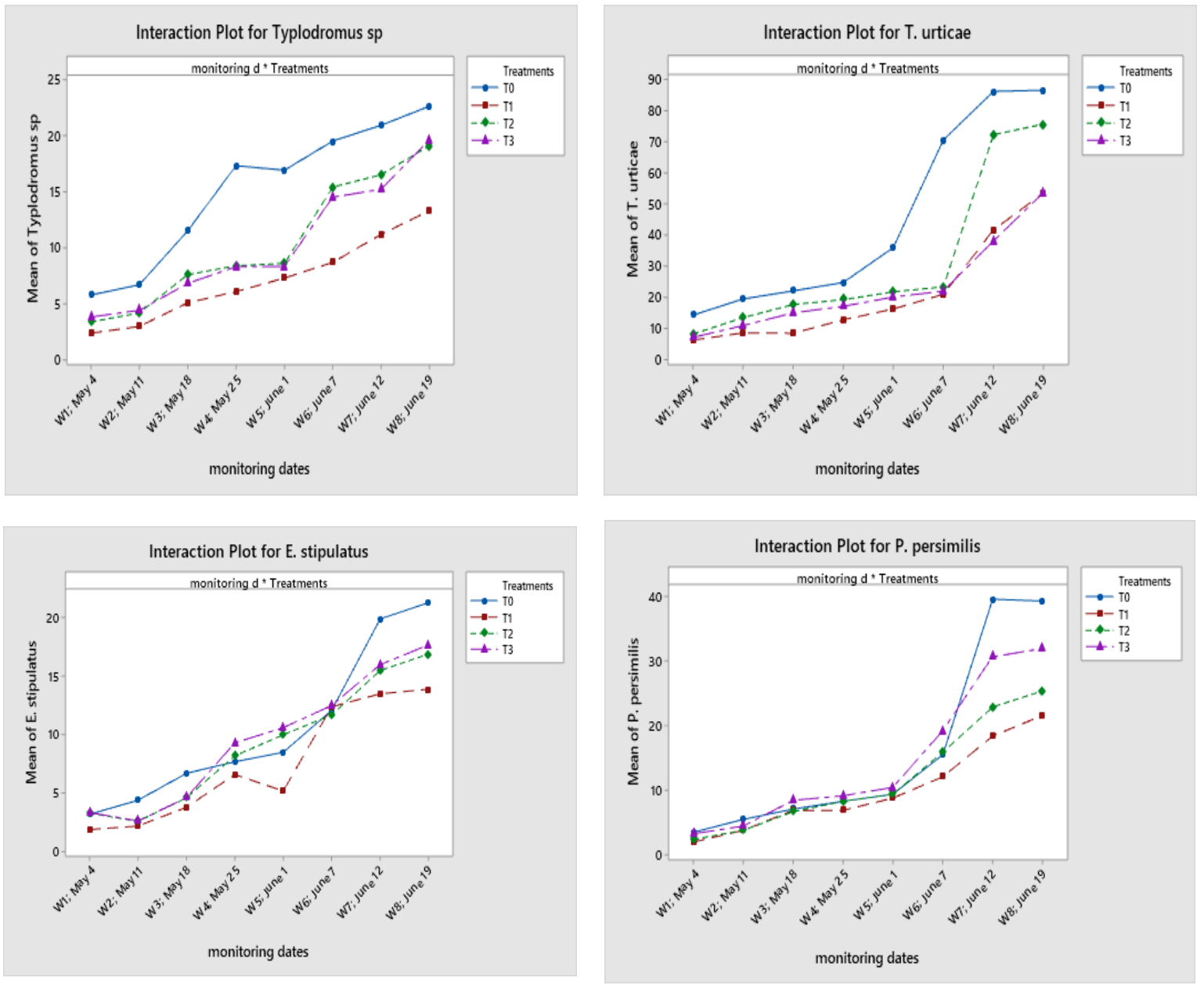

Figure 6. Variation of the means of T. urticae and their predators (ES: E. stipulatus; TY: Typhlodromus sp.; PP: P. persimilis $)$ in the four plots $(\mathrm{T} 0=$ control experiment; $\mathrm{T} 1=$ spirodiclofen $0.5 \mathrm{~L} / \mathrm{Ha} ; \mathrm{T} 2=125 \mathrm{~L} / \mathrm{Ha}$ $(5 \%)$ of black soap; T3 = detergent; $4 \mathrm{~L} / \mathrm{Ha}$ of Oni product $+2 \mathrm{~L} / \mathrm{Ha}$ of Tide product) according to the interaction between different monitoring dates and treatments $(\mathrm{d}=$ dates$)$. 
Table 3. Fluctuation of the different species studied (TU: T. urticae; ES: E. stipulatus; TY: Typhlodromus sp.; PP: P. persimilis) in the four treated plots (T0 = control experiment; T1 = spirodiclofen $0.5 \mathrm{~L} / \mathrm{Ha} ; \mathrm{T} 2=125 \mathrm{~L} / \mathrm{Ha}(5 \%)$ of black soap; T3 = detergents; $4 \mathrm{~L} / \mathrm{Ha}$ of Oni product $+2 \mathrm{~L} / \mathrm{Ha}$ of Tide product) according to the different monitoring dates (W: week).

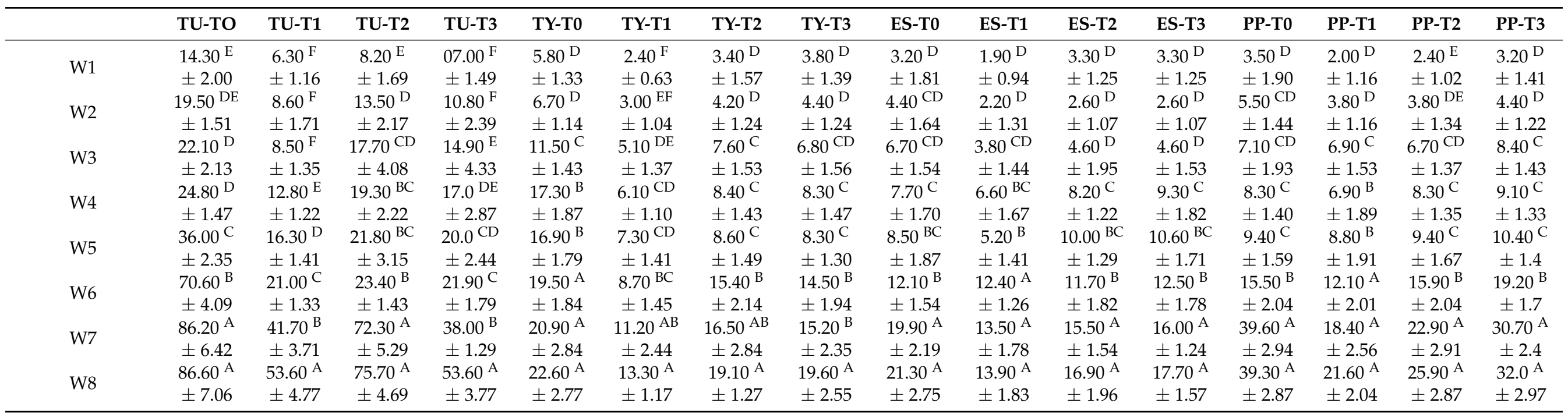

Values in the same column with different superscripts are significantly different $(p<0.05)$. 
For the treatment based on detergents, we obtained similar results to those achieved with spirodiclofen. These products ensured a significant reduction of the pest T. urticae during the eight-week monitoring period. Despite the increase in temperature from $27^{\circ} \mathrm{C}$ to $38^{\circ} \mathrm{C}$ (Table 4 ), the treatment with black soap ensured a significant decrease in the rates of T. urticae during the first six weeks after application compared to the untreated plot (Figure 6). During the sixth week, these averages were $23.40 \mathrm{~B} \pm 1.43$ on the plot sprayed with black soap and $70.60 \mathrm{~B} \pm 4.09$ on the untreated plot. The number of this pest increased during the last 2 weeks of monitoring (weeks 7 and 8) to reach $75.70 \mathrm{~A} \pm 4.69$ in week 8 , almost the same as the average reached on the untreated plot $(86.60 \mathrm{~A} \pm 7.06)$.

Table 4. Temperatures recorded during the monitoring period.

\begin{tabular}{lcccccccc}
\hline $\begin{array}{c}\text { Follow-Up } \\
\text { Date }\end{array}$ & $\begin{array}{c}\mathbf{4} \\
\text { May }\end{array}$ & $\begin{array}{c}\mathbf{1 1} \\
\text { May }\end{array}$ & $\begin{array}{c}\mathbf{1 8} \\
\text { May }\end{array}$ & $\begin{array}{c}\mathbf{2 5} \\
\text { May }\end{array}$ & $\begin{array}{c}\mathbf{1} \\
\text { June }\end{array}$ & $\begin{array}{c}\mathbf{7} \\
\text { June }\end{array}$ & $\begin{array}{c}\mathbf{1 2} \\
\text { June }\end{array}$ & $\begin{array}{c}\mathbf{1 9} \\
\text { June }\end{array}$ \\
\hline Temperature & 27 & 28 & 30 & 32 & 34 & 38 & 37 & 39 \\
\hline
\end{tabular}

During the whole monitoring period, Figure 6 indicates that the three treatments used caused a decrease in the means of T. urticae from 12 April (week 1) to 19 May (week 8) compared to the untreated plot; the effectiveness of spirodiclofen was important compared to the control by black soap and detergents.

Regarding the interaction between treatments and monitoring dates (Figure 6), all three treatments used had a significant impact on the abundance of Typhlodromus sp. over time. This influence was greater in the spirodiclofen than the detergent and black soap treatments.

For Typhlodromus sp., this difference was less important during the first five weeks after spraying the treatments. On the date of 18 May, these averages were $7.30 \mathrm{CD} \pm 1.41$ in T1 (spirodiclofen), $8.60 \mathrm{C} \pm 1.49$ in T2 (black soap), and $8.30 \mathrm{C} \pm 1.30$ in T3 (detergents). Then, there was a significant difference between the treatment with spirodiclofen and the treatments with black soap and detergents from the sixth week until the last week. The averages were $8.70 \mathrm{BC} \pm 1.45$ in $\mathrm{T} 1,15.40 \mathrm{~B} \pm 2.14$ in $\mathrm{T} 2$, and $14.50 \mathrm{~B} \pm 1.94$ in $\mathrm{T} 3$.

During the first five weeks, the detergent and black soap treatments showed less harmful impacts compared to spirodiclofen on the E. stipulatus population. The averages at this time (1 June) were $5.20 \mathrm{~B} \pm 1.41$ in $\mathrm{T} 1$ (spirodiclofen), $10.00 \mathrm{BC} \pm 1.29 \mathrm{in} \mathrm{T} 2$ (black soap), and $10.60 \mathrm{BC} \pm 1.71$ in $\mathrm{T} 3$ (detergents).

For $P$. persimilis, the detergent treatment showed almost similar results as in the control, and showed the least harmful impact, in the last three weeks of the follow-up (from 7 to 19 June). In the plot treated with detergents, we had an average of $32.0 \mathrm{~A} \pm 2.97$ for this species; in the untreated plot, we had $39.30 \mathrm{~A} \pm 2.87$; in the plot treated with black soap, the average was $25.90 \mathrm{~A} \pm 2.87$; and the average was $21.60 \mathrm{~A} \pm 2.04$ in the one treated with spirodiclofen.

\section{Discussion}

The biodiversity of phytoseiid mites nationally and internationally has started to decline catastrophically, as well as the increase in resistance developed by the pests against acaricides, allowing unusual increases in the population of the latter. This work aims to compare the impact of detergents, black soap, and spirodiclofen on the pest T. urticae on the one hand and on phytoseiid mites on the other hand.

The results collected during the study period showed that the three treatments used, namely, spirodiclofen, black soap, and detergents, ensured a decrease in the population rate of the pest T. urticae compared to the untreated plot. In the untreated plot, the average was $45.01 \mathrm{~A} \pm 4$. 90 mobile forms, while the plot treated with spirodiclofen was only $21.10 \mathrm{C} \pm 2.71$, the black soap gave $31.49 \mathrm{~B} \pm 3.35$, and average of the plot treated with detergents was similar to that obtained by spirodiclofen at $22.90 \mathrm{C} \pm 2.18$. The same results were reported by $[26,37]$ : the application of spirodiclofen ensured the decrease of 
the survival rate and fecundity of T. urticae. In another study, the efficacy of spirodiclofen and other acaricides against T. urticae on greenhouse strawberries was tested at different times after application. At seven days, spirodiclofen showed significant efficacy at 86.6\%. This efficacy reached $90 \%$ on day 10 and started to decrease slightly after that period [38]. In addition, black soap also showed significant efficacy against several insects such as Bemisia tabaci Gennadius, 1889, Aphis craccivora Koch, 1854 and parlatoria ziziphi Lucas, $1853[39,40]$. The pesticidal activity of the agricultural detergents SU-120 and Tecsa ${ }^{\circledR}$ Fruta was evaluated on T. urticae and Myzus persicae Sulzer, 1776. Several concentrations of SU-120 were applied to nymphs and adults of T. urticae. Mortality was measured in both cases at $24 \mathrm{~h}$. On T. urticae, both detergents caused mortality greater than $70 \%$ [41-43].

This study revealed that all three treatments used had an impact on the predators studied compared to the control, with the influence of spirodiclofen being greater than that of the detergents and black soap treatments. The effect of spirodiclofen was studied on Neoseiulus californicus McGregor, 1954, a potential predator of T. urticae, and the results indicated that the adverse consequences on the population growth parameters were significant [44]. In a small field plot test on spirodiclofen-treated apple trees, its use in a conventional chemical control program affected populations of Forficula auricularia Linnaeus, 1758 (Dermaptera), which is an important generalist predator in orchards, regulating populations of several damaging pest species, while the number of earwigs increased in the orchards with the compatible spray program (Integrated Pest Management) [45]. Many studies confirm that black soap and detergents can replace conventional chemical treatments and constitute an important tool in integrated pest management because of their low phytotoxicity $[43,46]$.

The results revealed that there was an impact of the treatments used on the three predators compared to the control, and this influence was greater with the spirodiclofen than with the detergents and black soap treatments. Despite the benefits of pesticides, such as the rapidity of action in the reduction of number of pests and their easy use when compared to natural extracts from plants [16], chemical control has many limitations; the examination of the action spectrum of the active components used throughout the world reveals that $46 \%$ of acaricides and $72 \%$ of insecticides are globally toxic towards auxiliary arthropods and public health [47]. Concerning the impact of the treatments according to the dates on T. urticae, we noticed that the three treatments ensured a decrease in the abundance of this pest. On the other hand, the efficacy of spirodiclofen was superior to the black soap and detergents; this can be explained by the high toxicity of the pesticide [22], as it can be remedied by monthly repetitive spraying with black soap or/and detergents, which remain less toxic for the plant, the predators, and the agroecosystem in general [39]. Botanical pesticides from the Lamiaceae, the Asteraceae, the Myrtaceae, and the Apiaceae taxons can also be used as a complementary alternative in the control of T. urticae [48]. We can explain the increase of the number of pests during the last two weeks of follow-up by the increase in the temperature, which remains a paramount parameter for population fluctuation $[49,50]$.

\section{Conclusions}

The following conclusions can be drawn from this work: the black soap and detergent products can replace conventional chemical treatments and are an important tool in integrated pest management, provided they are used correctly. The repetitive spraying of eco-friendly products can ensure the reduction of the pest rates in the long term. Finally, the release of natural enemies can be ensured after four weeks of the treatment with these products, since their persistence does not exceed five weeks, according to our results.

Author Contributions: Conceptualization, A.A. and A.L.; methodology, A.A.; investigation, M.K.; data curation, H.M.; writing-original draft preparation, A.A.; writing, review and editing, F.A.A.-M. and F.N.; supervision, A.L. and A.F. All authors have read and agreed to the published version of the manuscript. 
Funding: This research was funded by Researchers Supporting Project number (RSP-2021/112), King Saud University, Riyadh, Saudi Arabia.

Institutional Review Board Statement: Not applicable.

Informed Consent Statement: Not applicable.

Data Availability Statement: Data available upon request.

Acknowledgments: The authors are grateful for Researchers Supporting Project number (RSP2021/112), King Saud University, Riyadh, Saudi Arabia. Open access funding provided by University of Helsinki.

Conflicts of Interest: The authors declare no conflict of interest.

\section{References}

1. Citrus Fruit Fresh and Processed Statistical Bulletin 2020 I Policy Support and Governance I Food and Agriculture Organization of the United Nations. Available online: https:/ /www.fao.org/policy-support/tools-and-publications/resources-details/fr/c/14 39010/ (accessed on 28 January 2022).

2. Bora, H.; Kamle, M.; Mahato, D.K.; Tiwari, P.; Kumar, P. Citrus essential oils (CEOs) and their applications in food: An overview. Plants 2020, 9, 357. [CrossRef] [PubMed]

3. Tahir, R. Impact of Foliar Application of Zn on Growth Yield and Quality Production of Citrus: A Review. Indian J. Pure Appl. Biosci. 2020, 8, 529-534. [CrossRef]

4. Afechtal, M.; Djelouah, K.; Cocuzza, G.; D'Onghia, A.M. Large Scale Survey of Citrus Tristeza Virus (CTV) and Its Aphid Vectors in Morocco. Acta Hortic. 2015, 1065, 753-757. [CrossRef]

5. Mazih, A. Status of citrus IPM in the southern mediterranean basin Morocco, North Africa. Acta Hortic. 2015, 1065, 1097-1104. [CrossRef]

6. Rachid, E.; Ahmed, M. Current status and future prospects of ceratitis capitata wiedemann (Diptera: Tephritidae) control in Morocco. J. Entomol. 2018, 15, 47-55. [CrossRef]

7. Assouguem, A.; Kara, M.; Benmessaoud, S.; Mechchate, H.; El Jabboury, Z.; Farah, A.; Lazraq, A. Ceratitis capitata Wiedemann (Diptera:Tephritidae) in Moroccan Citrus orchards: Chemical and Sustainable Control Methods and Priorities for Future Research. Trop. J. Nat. Prod. Res. 2021, 5, 1703-1708.

8. Assouguem, A.; Kara, M.; Mansouri, I.; Imtara, H.; Alzain, M.N.; Mechchate, H.; Conte, R.; Squalli, W.; Farah, A.; Lazraq, A. Evaluation of the effectiveness of spirotetramat on the diaspine scale parlatoria pergandii in citrus orchards. Agronomy 2021, 11, 1562. [CrossRef]

9. Smaili, M.C.; El Ghadraoui, L.; Gaboun, F.; Benkirane, R.; Blenzar, A. Impact of some alternative methods to chemical control in controlling aphids (Hemiptera: Sternorrhyncha) and their side effects on natural enemies on young Moroccan citrus groves. Phytoparasitica 2014, 42, 421-436. [CrossRef]

10. Smaili, M.C. Current Pest Status and the Integrated. Available online: https:/ / scholar.google.com/scholar?hl=fr\&as_sdt=0\%2C5 $\& q=$ Smaili+MC+\%282017\%29+Current+pest+status+and+the+integrated+pest+management+strategy+in+the+citrus+groves+in+ Morocco.+In\%3A+Abstracts+of+the+IOBC+citrus+working+group+meeting+on+citrus+pests \%2C+disea (accessed on $10 \mathrm{July} 2021$ ).

11. Xue, W.; Snoeck, S.; Njiru, C.; Inak, E.; Dermauw, W.; Van Leeuwen, T. Geographical distribution and molecular insights into abamectin and milbemectin cross-resistance in European field populations of Tetranychus urticae. Pest Manag. Sci. 2020, 76, 2569-2581. [CrossRef]

12. Migeon, A.; Nouguier, E.; Dorkeld, F.; Cbgp, U.M.R.; Ird, I.; Montpellier, C.; Cedex, M. Spider Mites Web: A comprehensive database for the Tetranychidae Alain. Trends Acarol. 2010, 557-560. [CrossRef]

13. Grbić, M.; Van Leeuwen, T.; Clark, R.M.; Rombauts, S.; Rouzé, P.; Grbić, V.; Osborne, E.J.; Dermauw, W.; Ngoc, P.C.T.; Ortego, F.; et al. The genome of Tetranychus urticae reveals herbivorous pest adaptations. Nature 2011, 479, 487-492. [CrossRef] [PubMed]

14. Fakhour, S. L' acarien jaune, Tetranychus urticae Koch. (Acari: Tetranychidae) sur Maïs fourrager au Maroc: Impact et stratégies de lutte. In Proceedings of the Deuxième Colloque sur les Acariens des Cultures, Montpellier, France, 24-25 October 2005.

15. Nachman, G.; Zemek, R. Interactions in a tritrophic acarine predator-prey metapopulation system V: Within-plant dynamics of Phytoseiulus persimilis and Tetranychus urticae (Acari: Phytoseiidae, Tetranychidae). Exp. Appl. Acarol. 2003, $29,35-68$. [CrossRef] [PubMed]

16. Attia, S.; Grissa, K.L.; Lognay, G.; Bitume, E.; Hance, T.; Mailleux, A.C. A review of the major biological approaches to control the worldwide pest Tetranychus urticae (Acari: Tetranychidae) with special reference to natural pesticides: Biological approaches to control Tetranychus urticae. J. Pest Sci. 2013, 86, 361-386. [CrossRef]

17. Smaili, M.C.; Boutaleb-Joutei, A.; Blenzar, A. Beneficial insect community of Moroccan citrus groves: Assessment of their potential to enhance biocontrol services. Egypt. J. Biol. Pest Control 2020, 30, 47. [CrossRef]

18. De Maeyer, L.; Geerinck, R. The multiple target use of spirodiclofen (Envidor 240 SC) in IPM pomefruit in Belgium. Commun. Agric. Appl. Biol. Sci. 2009, 74, 225-232. 
19. Ramdani, C.; El Fakhouri, K.; Sbaghi, M.; Bouharroud, R.; Boulamtat, R.; Aasfar, A.; Mesfioui, A.; Bouhssini, M. El Chemical Composition and Insecticidal Potential of Six Essential Oils from Morocco against Dactylopius opuntiae. Insects 2021, $12,1007$. [CrossRef]

20. Daniel, E.C.; Wyss, C.L. Applications de soufre en automne: Une nouvelle manière de lutter contre lériophyide à galles du poirier. Rev. Suisse Vitic. Arboric. Hortic. 2004, 36, 199-203.

21. Buitenhuis, R.; Brownbridge, M.; Brommit, A.; Saito, T.; Murphy, G. How to start with a clean crop: Biopesticide dips reduce populations of Bemisia tabaci (Hemiptera: Aleyrodidae) on greenhouse poinsettia propagative cuttings. Insects 2016, 7, 48. [CrossRef]

22. Attia, S.; Grissa, K.L.; Zeineb, G.G.; Mailleux, A.C.; Lognay, G.; Hance, T. Assessment of the acaricidal activity of several plant extracts on the phytophagous mite Tetranychus urticae (Tetranychidae) in Tunisian citrus orchards. Bull. Soc. R. Belg. D'Entomol. 2011, 147, 71-79.

23. Van Leeuwen, T.; Tirry, L.; Yamamoto, A.; Nauen, R.; Dermauw, W. The economic importance of acaricides in the control of phytophagous mites and an update on recent acaricide mode of action research. Pestic. Biochem. Physiol. 2015, 121, 12-21. [CrossRef]

24. Saber, M.; Ahmadi, Z.; Mahdavinia, G. Sublethal effects of spirodiclofen, abamectin and pyridaben on life-history traits and life-table parameters of two-spotted spider mite, Tetranychus urticae (Acari: Tetranychidae). Exp. Appl. Acarol. 2018, 75, 55-67. [CrossRef] [PubMed]

25. Bostanian, N.J.; Trudeau, M.; Lasnier, J. Management of the two-spotted spider mite, Tetranychus urticae [Acari: Tetranychidae] in eggplant fields. Phytoprotection 2003, 84, 1-8. [CrossRef]

26. Hu, J.; Wang, C.; Wang, J.; You, Y.; Chen, F. Monitoring of resistance to spirodiclofen and five other acaricides in Panonychus citri collected from Chinese citrus orchards. Pest Manag. Sci. 2010, 66, 1025-1030. [CrossRef]

27. Faria, J.M.S.; Rodrigues, A.M. Essential Oils as Potential Biopesticides in the Control of the Genus Meloidogyne: A Review. Biol. Life Sci. Forum 2021, 3, 26. [CrossRef]

28. Assouguem, A.; Kara, M.; Mechchate, H.; Alzain, M.N.; Noman, O.M.; Imtara, H.; Hano, C.; Ibrahim, M.N.; Benmessaoud, S.; Farah, A.; et al. Evaluation of the Effect of Different Concentrations of Spirotetramat on the Diaspine Scale Parlatoria ziziphi in Citrus Orchards. Agronomy 2021, 11, 1840. [CrossRef]

29. Benyahia, H.; Talha, A.; Fadli, A.; Chetto, O.; Omari, F.E.; Beniken, L. Performance of 'Valencia late' sweet orange (Citrus sinensis) on different rootstocks in the gharb region (Northwestern Morocco). Annu. Res. Rev. Biol. 2017, 20, 1-11. [CrossRef]

30. Hassouni, T.; Belghyti, D. Distribution of gastrointestinal helminths in chicken farms in the Gharb region-Morocco. Parasitol. Res. 2006, 99, 181-183. [CrossRef]

31. Eur-lex EUR-Lex-31999L0045-EN_EUR-Lex. Available online: https:/ / eur-lex.europa.eu/legal-content/FR/ALL/?uri=celex: 31999L0045 (accessed on 30 November 2021).

32. Bouharroud, R. Acariens clés des Agrumes au Maroc, Agriculture du Maghreb. Available online: http://www.agri-mag.com/20 17/06/acariens-cles-des-agrumes-au-maroc/ (accessed on 18 April 2021).

33. Martínez-Ferrer, M.T.; Jacas, J.A.; Ripollés-Moles, J.L.; Aucejo-Romero, S. Approaches for sampling the twospotted spider mite (Acari: Tetranychidae) on clementines in Spain. J. Econ. Entomol. 2006, 99, 1490-1499. [CrossRef]

34. Marullo, R.; Bonsignore, C.P.; Vono, G. Thrips: A review of sampling methods in relation to their habitats. Bull. Insectol. 2021, 74, 241-251.

35. Benziane, T.; Abbassi, M.; Bihi, T. Evaluation de deux méthodes de lutte intégrée contre les ravageurs en vergers d'agrumes. J. Appl. Entomol. 2003, 127, 51-63. [CrossRef]

36. Haddad, D.N.; Sadoudi, F.G.-M. Management of a main citrus pest black parlatoria scale Parlatoria ziziphi (lucas) (hemiptera: Diaspididae) in the mediterranean basin. SciFed Virol. Res. J. 2018, 1, 184-199.

37. Van Pottelberge, S.; Khajehali, J.; Van Leeuwen, T.; Tirry, L. Effects of spirodiclofen on reproduction in a susceptible and resistant strain of Tetranychus urticae (Acari: Tetranychidae). Exp. Appl. Acarol. 2009, 47, 301-309. [CrossRef] [PubMed]

38. Wang, Z.; Cang, T.; Wu, S.; Wang, X.; Qi, P.; Wang, X.; Zhao, X. Screening for suitable chemical acaricides against two-spotted spider mites, Tetranychus urticae, on greenhouse strawberries in China. Ecotoxicol. Environ. Saf. 2018, 163, 63-68. [CrossRef] [PubMed]

39. Egho, E.; Emosairue, S. Evaluation of native soap (local black soap) for the control of major insect pests and yield of cowpea (Vigna unguiculata (L) WALP in ASABA, Southern Nigeria. Agric. Biol. J. N. Am. 2010, 1, 938-945. [CrossRef]

40. ABD-RABOU, S. Evaluation of Aphytis melinus De Bach (Hymenoptera: Chalcidoidea: Aphelinidae) in Citrus Orchards as a Biocontrol Agent of Black Scale, Parlatoria ziziphi (Lucas) (Hemiptera: Coccoidea: Diaspididae) in Egypt. J. Biol. Control 2009, 23, 37-41. [CrossRef]

41. Gill, H.K.; Goyal, G. (Eds.) Integrated Pest Management (IPM): Environmentally Sound Pest Management; IntechOpen: London, UK, 2016. Available online: https://www.intechopen.com/books/5252 (accessed on 28 January 2022).

42. Curkovic, T.; Araya, J.; Canales, C.; Medina, Á. Evaluation of two agriculture detergents as control alternatives for green peach aphid and twospotted spidermite, two pests affecting peach orchards in Chile. Acta Hortic. 2006, 713, 405-407. [CrossRef]

43. Curkovic, T. Detergents and Soaps as Tools for IPM in Agriculture. In Integrated Pest Management (IPM): Environmentally Sound Pest Management; IntechOpen: London, UK, 2016. Available online: https://www.intechopen.com/chapters/51590 (accessed on 28 January 2022). 
44. Sarbaz, S.; Goldasteh, S.; Zamani, A.A.; Solymannejadiyan, E.; Vafaei Shoushtari, R. Side effects of spiromesifen and spirodiclofen on life table parameters of the predatory mite, Neoseiulus californicus McGregor (Acari: Phytoseiidae). Int. J. Acarol. 2017, 43, 380-386. [CrossRef]

45. Fountain, M.T.; Harris, A.L. Non-target consequences of insecticides used in apple and pear orchards on Forficula auricularia L. (Dermaptera: Forficulidae). Biol. Control 2015, 91, 27-33. [CrossRef]

46. Bajwa, U.; Singh Sandhu, K. Effect of handling and processing on pesticide residues in food-a review. J. Food Sci. Technol. 2014, 51, 201-220. [CrossRef]

47. Van Leeuwen, T.; Vontas, J.; Tsagkarakou, A.; Dermauw, W.; Tirry, L. Acaricide resistance mechanisms in the two-spotted spider mite Tetranychus urticae and other important Acari: A review. Insect Biochem. Mol. Biol. 2010, 40, 563-572. [CrossRef]

48. Rincón, R.A.; Rodríguez, D.; Coy-Barrera, E. Botanicals against Tetranychus urticae Koch under Laboratory Conditions: A Survey of Alternatives for Controlling Pest Mites. Plants 2019, 8, 272. [CrossRef]

49. Bayu, M.S.Y.I.; Ullah, M.S.; Takano, Y.; Gotoh, T. Impact of constant versus fluctuating temperatures on the development and life history parameters of Tetranychus urticae (Acari: Tetranychidae). Exp. Appl. Acarol. 2017, 72, 205-227. [CrossRef]

50. Abdallah, A.M.; Ismail, M.S.M.; AboGhalia, A.H.; Soliman, M.F.M. Factors affecting population dynamics of Tetranychus urticae and its predators on three economic plants in Ismailia, Egypt. Int. J. Trop. Insect Sci. 2019, 39, 115-124. [CrossRef] 